\title{
Strengthening Economic Civic in Forming Independence of Santri as the Good Governance (Case Study of Al-Ittifaq Islamic Boarding School, Rancabali, Bandung)
}

\author{
Zulkifli $^{1}$, Nurdiana $^{2}$, Muchsin $^{3}$ \\ 1,2,3 Jabal Ghafur University, Indonesia \\ Email: zulkiflipkn85@gmail.com,nurdiana@unigha.ac.id,muchsin@unigha.acid
}

\begin{abstract}
:
Development of pesantren role in empowering the community is one of the important efforts to strengthen the role of people in development because the government still faces a variety of cultural and structural problems, as well as the private sector tends to deviate to gain unilateral advantages. In exercising their development, empowerment is an approach that is relevant to strengthen the role of the community (civil society). The research objective was to analyze (1) the values instilled in the process of establishing the independence of the students through economy civic, (2) conceptual model and praxis of strengthening economy civic in establishing the independence of students as a form of good governance, (3) the factors strengthening economy civic in establish independence of students as a form of good governance. This study used a qualitative approach with case study method. Data collected through interviews, observation, documentation studies and literature studies. Subjects of research include builder boarding schools, boarding schools administrators, and students. Qualitative data analysis consists of three activities, namely data reduction, a data display, and conclusion drawing / verification. The results showed some things (1) the values of self-reliance of students of pesantren Al-Ittifaq is highlight the work ethic, high discipline, and ready for hard work, (2) conceptual model in establishing the independence of students with learning system AKOSA (naturally, pointed out, though, and apply). Praxis in forming the independence of the students through the formation of the core committee of agribusiness, doing practical training, forming Agribusiness Incubator Center (PIA), cooperation / partnership, and formed working groups agribusiness. As a manifestation of good governance pesantren Al-Ittifaq role as the private sector to foster public economic activities around the village of Natural Endah through cooperative Al-Ittifaq, while as civil society has been able to interact actively with various activities such as religious, economic, educational, social, and political. (3) The internal factors strengthening economic civic been producing products ranging from production (vegetables and livestock), packing, and marketing and external factors natural conditions Desa Alam Endah fertile, has been establishment of cooperation with farmers' groups, government agencies (Ministry of Commerce, Ministry of Agriculture, Ministry of Cooperatives and SMEs, and the Ministry of Social Affairs), educational institutions, businesses (Yogya Group, Toserba Banjaran, Kopo Mall).
\end{abstract}

Keywords:

economy civic; independence; good governance

\section{Introduction}

The journey of Indonesian independence has lasted approximately 70 years of independence. The statement that first appeared to regulate the formation of the territory of the state of Indonesia was "The State of Indonesia is a unitary state in the form of the Republic" (Article 1 of the 1945 Constitution of the Republic of Indonesia). The statement is a logical consequence that as a unitary state is the formation of the Indonesian government as 


\section{Britain International of Humanities and Social Sciences (BIoHS) Journal \\ ISSN: 2685-3868(Online), 2685-1989(Print) \\ Vol. 2, No. 2, June 2020, Page: 429-439}

a national government for the first time and then the national government then forms the region in accordance with statutory provisions. This is the forerunner to the birth of regional autonomy. As a legal basis to regulate the implementation of regional autonomy in Article 18 paragraph (2) and paragraph (5) of the 1945 Constitution of the Republic of Indonesia states the following: Regional government has the authority to regulate and manage their own affairs according to the principle of autonomy and co-administration and given the widest possible autonomy (Article 18 paragraph (2). Giving the widest possible autonomy to the regions is directed to accelerate the realization of people's welfare through improving services, empowering In addition, through broad autonomy, in the strategic environment of globalization, Regions are expected to be able to increase competitiveness by taking into account the principles of democracy, equity, justice, privileges and specificities as well as the potential and diversity of Regions in the system of the Unitary State of the Republic of Indonesia. (Article 18 verses (5).

From the above statement that the granting of autonomy to the greatest extent possible is carried out based on the principle of the unitary state. In a unitary state sovereignty is only in the state government or national government and there is no sovereignty in the regions. Therefore, no matter how much autonomy is given to the regions, the final responsibility for implementing regional government will remain in the hands of the central government. For this reason, regional government in a unitary state is a unity with the national government. Accordingly, policies made and implemented by the regions are an integral part of national policies. The difference lies in how to utilize the wisdom, potential, innovation, competitiveness, and creativity of the region to achieve these national goals at the local level which in turn will support the achievement of national goals as a whole.

In line with the necessity to form regional government in the administration system of the Indonesian state, since the proclamation of independence until now the Indonesian state has issued various laws concerning the implementation of regional autonomy. The birth of Law Number 23 of 2014 concerning Regional Government is the seriousness of the central government in welcoming the implementation of regional autonomy. Regional autonomy opens opportunities as wide as possible for the region to actualize all the best potential optimally. That way each region undoubtedly has one or several specific advantages relative to other regions. Even in terms of potential advantages can be absolute, for example, which comes from the aspect of location or endowment. But this new opportunity or opportunity, is not something that is automatically realized. Some prerequisites are needed to prepare regions to become active players in the global market arena according to Center for Institutional Reform and the Informal Sector (IRIS) University of Maryland at College Park (2001: 2) are as follows : (a). Guaranteed free movement of all factors of production, goods and services within the territory of Indonesia, except for cases based on non-economic arguments. (b). A political process that also guarantees the economics of local communities in determining and fighting for their aspirations through political participation in the decision making process that impacts the public. (c). The establishment of good governance, both at the central and regional levels, so that regional autonomy does not create new forms of KKN. (d). Regional openness to collaborate with other neighboring regions to optimize the management of available resources. (e). The flexibility of the incentive system. (f). The role of local government is more as a regulator which aims to protect minority groups and the weak and maintain harmony with the natural surroundings, not regulators in the sense of regulating.

One aspect of organizing and realizing the goals of regional autonomy is the independence of the region and its people. Talking about the independence of the community 
an important aspect for the achievement of independence is the quality of Indonesian people. The problems faced by the Indonesian people now according to Al-Muchtar (2015, p. 75 ) are the quality of Indonesian people is questioned in the fading of values of independence, cultivating values of corruption, understanding the spirit of hard work, unyielding spirit, a spirit of struggle that can give birth to surrender to apathy, avoiding difficulties, wanting to always get "wisdom" even if it violates the general agreement. These symptoms need to be taken seriously in an effort to foster and improve the quality of Indonesian people today and in the future.

From the description above it can be analyzed that in fact it has long been realized about the dimensions of the education crisis which is more focused on the crisis of independence of students and the output of schools, students, and even college graduates. Substantively-educative in Law Number 20 Year 2003 regarding the National Education System must be aimed at producing mature Indonesian people who "believe in and fear God Almighty, have noble, healthy, knowledgeable, capable, creative, independent, and become citizens. Democratic and responsible state". As outlined as the goal of national education the aspect of independence is one of the important aspects in the formulation to be achieved by our nation. Furthermore, in article 13 paragraph (1) of Law Number 20 Year 2003 concerning the National Education System confirms that "The education channel consists of formal education, non-formal education, and informal education that can complement each other".

In the path of education that has been described above boarding schools are Islamic institutions that enter into formal and non formal education. According to Rofiq A, et al (2001) say that pesantren as non-formal education such as traditional boarding schools, majelis taklim, sarekat please help, and the assemblies of culture. Whereas the formal pesantren education pathway is a pesantren which has permanent learning methods and models. From the description above, it can be concluded that non-formal pesantren are pesantren which provide traditional learning. Whereas pesantren which are included in formal institutions are pesantren that already have a learning system similar to the learning system in schooling.

Pesantren is an education system that has developed long before this country became independent. This education, which is often called traditional, along with madrassas and other national private education, has been instrumental in growing self-supporting and selfsupporting communities. This is what later on together with other social forces became the backbone and basis of the struggle for independence. Whatever development is carried out and lived by the pesantren does not change its main characteristics as an educational institution. The pesantren education system is based on the values of life which are based on the basic teachings of the Islamic religion. This is what underlies the concept of development and the role of pesantren institutions.

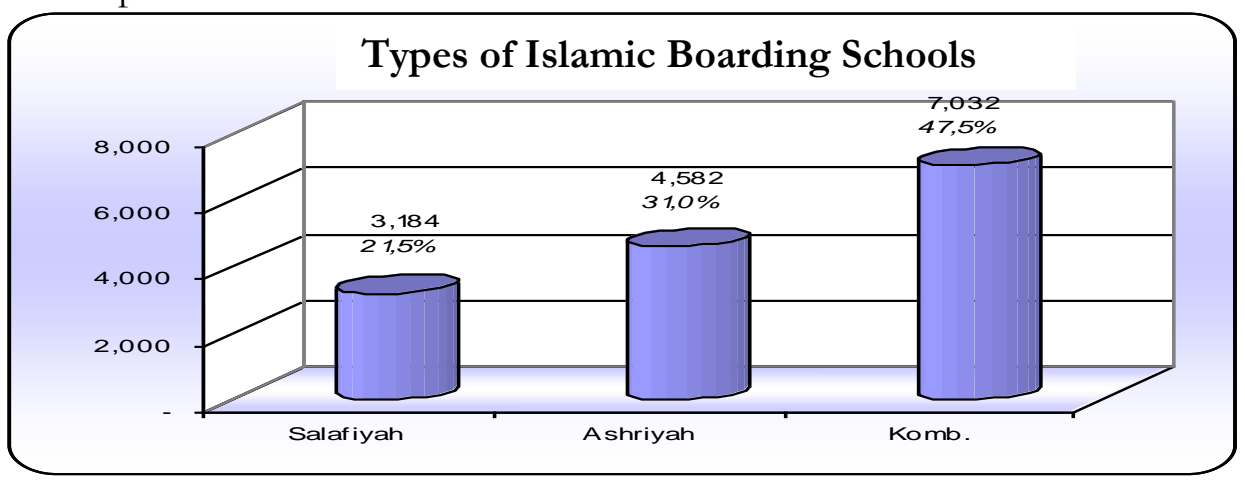

Figure 1. Types of Islamic Boarding Schools in Indonesia

Source: Author Processed in 2016 
Based on the types of boarding schools above there are 3,184 (21.5\%) are Salafiyah Islamic Boarding Schools, and 4,582 (31.0\%) Ashriyah, and 7,032 (47.0\%) as Combination Islamic Boarding Schools. The total number of santri was 3,464,334, consisting of 1,763,777 $(50.9 \%)$ mukim students, and 1,700,557 (49.1\%) non-resident santri. Based on learning activities in Islamic boarding schools, $40.6 \%$ of the students are only the Koran, and $59.4 \%$ of the students are the Koran and the school. The data of students throughout Indonesia can be seen as follows:

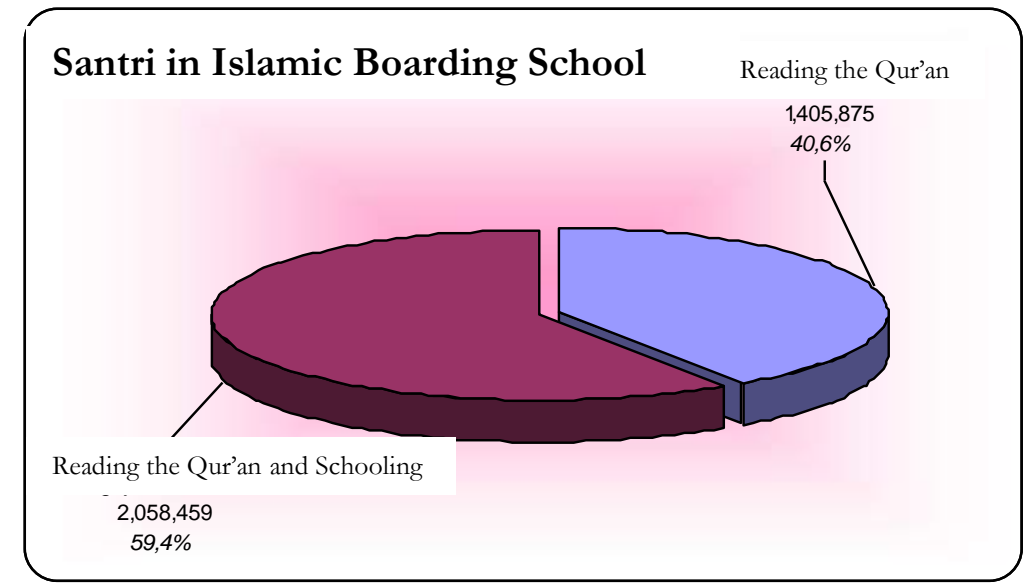

Figure 2. Number of Santri in Indonesia in 2004-2005

Source: Author Processed in 2016

From the data of the number of students above boarding schools in Indonesia has enormous potential as part of civil society in functioning or developing its role as an educational institution, missionary institution, and the institution of empowerment and community service in community empowerment. This functionalization is proof of participation that is needed in realizing good governance and achieving the main goal of regional autonomy, namely the independence of the region and the community.

\section{Review of Literatures}

Economic civics is one of the dimensions developed in Citizenship Education. As explained by Wahab and Sapriya (2011) that learning civics aside from being oriented to community civics it is necessary to introduce other Civics study branches such as economic civics and vocational civics that cannot be released between each other of the three civics branches because they have interconnectedness one another. Danial (2007) describes economic civics as developing concepts of economics that have been quite advanced, such as economic politics or economic policy. Economic politics is already quite developed by the experts who deepen it, because it is very difficult to separate politics and economics practically in state life.

The urgency of developing economic civics is due to the emergence of various problems that appear in the reality of national and state life today. First, the journey of democracy is not accompanied by an increase in the national economy; Second, the low creativity of citizens in creating something in relation to the development of economic life. Third, the high level of unemployment in Indonesia; Fourth, the paradigm is still strong that working is better than opening your own business; Fifth, the low interest and motivation of the community towards entrepreneurship; Sixth, the lack of courage in finding, developing and creating opportunities in efforts to improve life towards a better direction. Seventh, economic development in Indonesia is mostly money oriented; Eighth, the waning of national values; Ninth, the weak culture of entrepreneurship that is a source of creative human resources both produced by formal and non-formal education institutions. 
Speaking of Civic Education, it is never separated from two technical terms in a foreign literature, namely civic education and citizenship education. Cogan (1999, p. 4) emphasizes the difference in understanding of Civic Education with citizenship education. "Civic education" generally refers to "... the foundational course work in school designed to prepare young citizens for active roles in their communities in their adult lives", or a basic subject at school designed to prepare young citizens, so that later as an adult they can play an active role in their society.

Based on the above explanation it can be that the Civics Education focuses on the ability, attitudes and active thinking skills of citizens in internalizing the values of good citizens in accordance with the Pancasila and the 1945 Constitution. Meanwhile, David Kerr (1999, p. 2) states that Citizenship Education is broadly formulated to include the process of preparing young people to take up their roles and responsibilities as citizens, and in particular, the role of education including schooling, teaching and learning in the process of preparing these citizens. Seeing as according to David Keer's definition that Civics have a very large role in preparing the younger generation in playing their roles and responsibilities as citizens who must be taught in the learning process in both formal and informal environments. Furthermore Villegas Reimer (1997, p. 235) states that Citizenship Education has been described as "The constribution of education to the development of those characteristics of being a citizen" (Cogan, 1998, hlm. 3), and the "Process of teaching society's roles, istitutions, and organizations, and the role of citizens in the well-functioning of society.

As expressed by Villegas-Reimer Civics is described as an educational contribution to developing the characteristics of citizens, and the process of teaching rules in society, government, and organizations, and the role of society that functions well in the country. Meanwhile, Civics in Indonesia are expected to prepare students to become citizens who have a strong and consistent commitment to defend the Unitary State of the Republic of Indonesia (NKRI). The nature of the Unitary Republic of Indonesia is a modern nation-state. A modern nation state is a country whose formation is based on a national spirit, that is, the determination of a society to build a future together under the same country, even though the citizens of these peoples are of different religions, races, ethnicities, or groups. (Minutes of the Session of the Indonesian Independence Preparatory Agency / BPUPKI) and Indonesian Independence Preparatory Committee / PPKI).

The learning process in the classroom that uses the internet as a learning medium is expected to be part of a learning process at school, the internet is expected to be able to provide support for the implementation of an interactive communication process between teachers and students (Hamonangan, 2019). In connection with this understanding of Citizenship Education the Ministry of National Education (2006) provides an explanation that: Citizenship Education is a subject that focuses on the formation of citizens who understand and are able to carry out their rights and obligations to become intelligent, skilled, and characterized Indonesian citizens mandated by the Pancasila and the 1945 Constitution.

Considering the National Education Ministry's opinion above, the focus of the Civics Study as a subject is preparing citizens who understand and implement their rights and obligations in accordance with the mandate of the Pancasila and the 1945 Constitution of the Republic of Indonesia. Somantri (2001, p. 154) provides the formulation of the following understanding: Somantri (2001, p. 299) said that: Citizenship Education is an educational program with a core of political democracy that is expanded with other sources of knowledge, positive influences from school, community and parent education, all of which are processed 
to train students to think critically, analytically, behave and act democratically in prepare a democratic life based on Pancasila and the 1945 Constitution.

From Somantri's opinion above that Civics is preparing citizens in carrying out a democratic system in Indonesia that is based on Pancasila values through democratic actions and attitudes in accordance with the values of Pancasila and our country's constitution namely the 1945 Constitution of the Republic of Indonesia. When viewed philosophically, sociopolitical and pedagogical, Citizenship Education holds a sacred mission for the formation of a nation's dignified character and civilization in order to educate the life of the nation, and to make humans a democratic and responsible citizen (Winaputra and Budimansyah, 2007: 156).

\section{Research Methods}

The approach used in this research is to use a qualitative approach. Qualitative approaches are more natural, inductive, and find meaning from a phenomenon (Suwarma, 2015). Creswell (2008, p. 50) defines "Qualitative research is an inquiry process of understanding based on distinct methodological traditions of inquiry that explore a social or human problem. The researcher builds a complex, holistic picture, analyzes words, reports detailed views of informants, and conducts the study in a natural setting" This statement implies that the qualitative approach is an approach that emphasizes the interpretative study of research data and does not use quantification or statistical calculations. Research conducted by the author is research using the case study method. Gay et al (2009, p. 426) suggest case study research is a qualitative approach to studying a phenomenon, focused on a unit of study or a bounded system, not a methodological choice, but a choice of what to study, an allencompassing research method.

Case study research is a qualitative approach that is used to study phenomena, is focused or limited to one research unit, and is a research method that covers the whole research. Based on this understanding, it can be explained that the case study method is used to examine carefully and in detail about the things being studied. This research will produce something unique because it is research aimed at a unit.

\section{Discussion}

Islamic boarding schools organize education with the aim of instilling faith and piety in Allah SWT, noble morals, and pesantren traditions to develop the abilities, knowledge and skills of students to become experts in Islamic religion (mutafaqqih fiddin) and / or become Muslims who have the skills / expertise to building an Islamic life in the community. With the objectives of the pesantren above, it is expected to be able to strive for and develop the abilities, knowledge and skills of this Indonesian nation. Many of Indonesia's potential natural resources can be developed, but "impressed" with no effort and passivity in managerial processing. Therefore, a qualified education forum is needed in the development of human resource management (HRM) to develop and process natural resources (SDA) that are potential as an effort to respond to global challenges.

The results of interviews with the FA as the supervisor of the Al-Ittifaq boarding school that the background to the establishment of the Al-Ittifaq boarding school since 1970 felt that teaching activities alone would not be able to meet the needs of the students. Besides that he felt responsible for the independence of the students. So the Al-Ittfaq boarding school combines religious education activities with agricultural business activities in accordance with the natural potential around the pesantren. The concept of the Al-Ittifaq boarding school was 
initially only in the form of an ordinary pesantren (salafiyah) which only taught religious sciences, but now a formal education institution (khalafiyah) has been developed which combines boarding material with the government curriculum.

While ZN added that the Salafiyah Al-Ittifaq pesantren experienced developments both in terms of concepts and practices, seen from the study of lessons conducted such as Fiqh, Sufism, Nahwu, Sharaf, Al-Qur'an, Yellow Book (Safinah, Jurumiah, Fathul Qarib , Imriti, Riyadhul Badi'ah, Sulamun Taufiq, I'aanah, Bulughul Maram, and Irsyadul 'Ibad), Society (Social Sciences such as; Reception and Submission of Brides, Ceremony of Ijab Qabul, Shaving Baby Hair, Taking Care of Bodies), and activities extracurricular activities (agriculture, animal husbandry, packing, and supplier of goods). In addition to the pesantrenan activities, the Al-Ittifaq boarding school also develops the study sessions of the Islamic study group with material including Figh, Sufism and so on. As general material given to the students it was taken from various yellow books, some of which were translated into Javanese and Sundanese.

The findings of researchers with the coaches of the Al-Ittifaq FA boarding school that the Al-Ittifaq boarding school is a socio-religious organization that supports orphans and poor people and educates business development. With the intention of worship and upholding the symbols of Islam through da'wah, the Al-Ittifaq boarding school provides social services in the field of religious education combined with agricultural education. With the hope that the students will have strong faith and piety, be mentally independent and have an entrepreneurial spirit. The vision of the Al-Ittifaq boarding school is "sincere in the service of upholding the propagation of Islam through da'wah", while the mission it has is, forming individuals and people of noble character through the practice of Islamic values, developing integrated service programs, directed and sustainable, shape achievement behavior, think strategically and act effectively and efficiently through the development of a comprehensive education for eligibility.

The motto of Al-Ittfaq boarding school as explained by ZA as part of human resources (HR) that the Al-Ittifaq boarding school has a motto is Gapuraning rahayu nawa ing buana. Gapura means big door, rahayu means happiness and salvation, and nawa ing buana means for all nature. So that means that as much as possible can provide happiness and safety for the universe or laham alil alamin The value instilled by Al-Ittifaq pesantren to the students is the sunnatullah value of agribusiness. The value of sunnatullah can be described through the analogy of plants. ZA also gave an example in an analogy of planting. When a santri grows a crop, they do one good thing. First, plants will glorify God, both plants will be able to produce photosynthesis, photosynthesis will produce air, air can be inhaled by many people, thirdly when we already produce plants we sell, they can eat, be excited, live, worship. The philosophy of one plant is a value instilled Al-Ittifaq boarding school to the students.

As Bio Agribisnsis DM also explained that the types of agribusiness activities in the Al-Ittifaq boarding school include the activities of production processes (gardens), packing (product management), and marketing of agricultural products. The agribusiness activity was given by the leadership of the Al-Ittifaq boarding school with the aim to empower students so that after they became alumni of the students, they had the knowledge and skills in managing natural resources, in addition to printing to become a Ustadz. The same thing was explained by YY as the administrator of the Al-Ittifaq boarding school that what was felt during his stay at the Al-Ittifaq boarding school was that he could learn to live independently. One of the values held by the Al-Ittfaq pesantren according to YY is in accordance with the philosophy of the West Javanese people namely Silih Asah, Silih Asih, and Silih Asuh. Prostitution Asah is 
reminding each other in goodness and truth in life. Suki Asih is loving one another of humanity without regard to ethnicity, religion or race. Foster Care is to guide and invite each other with a heart that is based on kinship. This is what I felt while living at the Al-Ittifaq boarding school.

More clearly the philosophical meaning of the people of West Java explained by the FA that the philosophical foundation of Silih asih silih, foster and custody teach teach one another caring and loving, sharing knowledge and experience. This philosophy is influenced by the fertile and natural conditions of nature. The community is familiar with the environment and preserves it, making Sundanese people always close to Allah SWT and others. Philosophy of choice shows the character of a particular religious culture as a consequence of worldview. Suki asih is a form of social interaction based on the love of Allah SWT to beings, implemented in daily life through love for others. Compassion allows readiness for giving and receiving. The spirit of the deity of humanity in love gives birth to egalitarian values and morality (equality) in society. Compassionate society, mutual respect and do not consider others inferior. From the ethos and morality, they have the potential to live orderly, dynamically in harmony.

Philosophy of choice encourages people to develop themselves, sharing knowledge and technology for progress. Sharpening gives birth to a progressive ethos for the growth of independence and discipline, independent of others. In principle, reason because there is no jalma. Adigung adiguna's doing, my agut is an old umbrella. Whereas the philosophy of fostering requires mutual caring, fostering one another and helping the needy. Collective or personal interests are positioned to get serious attention through mutual control, admonishing, and advising each other. The power of reparation makes the lives of the people orderly and neat (peaceful and orderly). Jeung dulur caused by pacogregan, (with siblings there is no dispute allowed), kudu kawas dulur pet ku hinis, (treating others must be like with siblings), other deungeun-deungeun, (the fellow is not someone else). Kudu sabilulungan fall out of the mountain, (must be mutually support), sareundeuk saigel sabobot sapihanea, (remind each other when other people or neighbors take actions that are detrimental to society), nulung kanu need, nalang kanu difficult (giving help to those in need, and becoming a fort or person in charge for people affected by disaster). The philosophy of penance is not only clearly seen in social relations but in economic and business relations. They transact crops, plant seeds, fertilizers easily and trust each other. Even mutual support of capital is easy, unconditionally with the motive of advancing each other. Glorifying and prioritizing customers has become a daily routine that also leads to the flying of the brotherhood network between the parties involved in the whole process and post-business. From the consequences of the philosophy of West Java society, the principle of economic behavior of the business carried out dominates socio-economic distribution. This is in line with the direction of the implementation of the Islamic business economy in production, consumption and distribution, namely the realization of benefit. The success achieved can provide added value to others. The necessity of zakat for property, profession zakat in Islamic economics shows the strictness of nuances of socioeconomic distribution.

\section{Conclusion}

Strengthening the economic civic in shaping the independence of the Al-Ittifaq pesantren santri is carried out through its agribusiness activities by involving the santri in each of its activities, so that the santri are not only provided with religious knowledge, but are also equipped with agribusiness knowledge. The role of the Santri Alumni also does business in the field of agribusiness and is generally successful. Business activities undertaken by this 
pesantren have a multiple effect on the continuity of the education process at the Al-Ittifaq boarding school. Aside from being a suggestion for meeting the needs of pesantren residents, it can also have the value of competitive and comparative advantage and be a laboratory for the development of the independent spirit of the santri business.

At present the success achieved by Al-Ittifaq pesantren is that there are many $\mathrm{Al}$ Ittifaq pesantren alumni who have become recitation teachers, traders and there are also those who open new pesantren in their home regions, and as many as 36 DKM (Masjid Prosperity Board) are located in the area of Rancabali, Lebak Muncang and Ciwidey are alumni of AlIttifaq pesantren students. As a form of good governance, the Al-Ittifaq pesantren has officially become the first agribusiness consulting clinic as an Agribusiness Incubator Center (PIA) which is an incubation place to increase the independence of small businesses as beginners into more independent businesses, secondly as an agribusiness training center for the agribusiness students and the surrounding community are also farmers / SMEs from several regions and government agencies.

With the existence of agribusiness activities in the Al-Ittifaq boarding school not only benefit and improve the welfare of the managers and students, but also benefit and improve the welfare of the community around the village of Alam Endah. This was due to the efforts of the Al-Ittifaq boarding school, besides involving the santri also involving the local community, both in the production of a commodity and in the development of the pesantren cooperative and the Baitul Maal Wattamwil (BMT) Integrated Mandiri board.

\section{References}

Achmad Faozan. (2006). "Pondok Pesantren dan Pemberdayaan Ekonomi”, Ibda': Jurnal Studi Islam danBudaya, Vol 4, No. 1, 2006, 88-102

Asori, M dan Ali, M. (2008). Psikologi Remaja; Perkembangan Peserta Didik. Jakarta: PT. Bumi Aksara [online] http;//eprints.undip.ac.id

Audy Ayu Arisha Dewi dan Tience Debora Valentina . (2013). Hubungan Kelekatan Orangtua-Remaja dengan Kemandirian pada Remaja di SMKN 1 Denpasar. Jurnal Psikologi Udayana 2013, Vol. 1, No. 1, 181 -189

Al-Ittifaq, Pondok Pesantren. (1996). Anggaran Dasar Yayasan dan Anggaran Rumah Tangga Pondok Pesantren Al-Ittifaq, Akta Yayasan. Bandung: Pondok Pesantren Al-Ittifaq.

Amin Haedari, dkk. (2004).Masa depan pesantren: Dalam Tantangan Modernitas danTantangan Komplesitas Global. Jakarta: IRD PRESS,2004

Creswell, John W. (2008). Educational Research (Planning, Conducting andEvaluating Quantitative and Qualitatif Research (Third Edition). California: University of Nebrasca-Lincoln.

Danial, E. (2007). Economic Civic (Membina Warga Negara; Bersikap dan Berpartisipasi Dalam System Ekonomi Nasional Untuk Meningkatkan Kesejahteraan Masyarakat. Bandung: Laboratorium PKn UPI.

Danial, Endang. (2009). Metode Penulisan Karya Ilmiah. Bandung: Laboratorium Pendidikan Kewarganegaraan.

Experimental Analysis. Cambridge, Massachusetts: B.F. Skinner Foundation.

Hamonangan, et al. (2019). Student Learning Result of Citizenship Education in Internet Learning Media with High Interpersonal Communication in High School Al-Azhar Medan. Budapest International Research and Critics in Linguistics and Education (BirLE) Journal, 2(4); 491-498. 
Isa, H.A. (2012). Pengembangan Model Pelatihan Kecakapan Hidup Terintegrasi Dengan Nilai-Nilai Budaya Lokal Dalam Meningkatkan Kemandirian Berusaha. Disertasi Prodi PLS Pascassarjana UPI

Kartadinata, Sunaryo, 1988, Profil Kemandirian dan Orientasi Timbangan Sosial Mahasiswa serta Kaitannya dengan Perilaku Empatik dan Orientasi Rujukan Disertasi, FPS IKIP Bandung.

Kaswadi. (1993). Pendiidkan Nilai Memasuki Tahun 2000. Gramedia Widiasarana Indonesia.

Keputusan Menteri Pendayagunaan Aparatur Negara dan Reformasi Birokrasi Nomer 63/Kep/M.PAN/7/2003 tentang pedoman umum penyelenggaraan pelayanan publik

Kusumawardhani, A dan Hartati dkk. (2011). Hubunan Kemandirian Dengan Adversity Intelligence Pada Remaja Tunas Daksa Di SLB-D YPAC Surakarta. Tersedia diimamsetyawan.psiundip@gmail.com tanggal 20 Januari 2016

Lina Ria Erfiana. Hubungan antara Kebermaknaan Hidup dengan Kemandirian pada Remaja. Jurnal UAD

Lincoln, Y.S. \& Guba, E.G. (1985). Naturalistic Inquiry. Baverly Hills: Sage Publications.

Mardiasmo. (2002). Akuntansi Sektor Publik. Yogyakarta: Andi

Mastuhu. (1994). Dinamika Sistem Pendidikan Pesantren. Jakarta: INS

Megawangi, Ratna. (2004). Pendidikan Karakter: Solusi yang tepat untuk Membangun Bangsa. Jakarta: Star Energy (Kakap) Ltd

Miles, Matthew \& Huberman, A. Michael. (2007). Analisis Data Kualitatif. Jakarta : UI-Press

Moleong, J.X. (2000). Metode Penelitian Kualitatif.Bandung : PT Remaja Rosdakarya.

Mulyana, R. (2004). Mengartikulasi Pendidikan Nilai. Bandung: Alfabeta

Masyitoh, Iim. S. (2011). Pengembangan Pendidikan KarakterBerbasis Etnopedagogik. Disertasi. Bandung: Tidak Diterbitkan

Mu'tadin, Z. (2002). Kemandirian Sebagai Kebutuhan Psikologis Para Remaja.http/daffo dilmuslimah.multiply.com/journal/item/162/kemandirian, 13-12- 2009.8.06

Muctar, U.M. (2011). Implementasi Model Pembelajaran Kemandirian Berbasis Nilai Satya Dan Darma Pramuka Dalam Membentuk Generasi Muda Mandiri Melalui Kegiatan Alam Terbuka. Disertasi. Bandung: tidak diterbitkan

Muchsin, M. \& Mariati, M. 2020. Application of Based Learning Models in Improving Creative Thinking of Students at Physics Lessons in SMA Bandar Baru. Budapest International Research and Critics Intstitutr (BIRCI) Journal. 3(2) 1453-1458Muchsin, M \& Khumaedi, K. (2017) Analisis Ketrampilan mahasiswa calon guru dalam menjelaskan konsep mengunakan analogi pada pembelajaran fisika. Phusics Communication, 1(1), 23-33

Mungin Eddy Wibowo.Menyiapkan Bangkitnya Generasi Emas Indonesia. Artikel

Musdalifah. (2007).Perkembangan Sosial Remajadalam Kemandirian. Volume 4 Juli Desember 2007

Naftika Dyah Funnisa. Peran Pendidikan Nonformal Dalam Megantisipasi Dan Menanggulangi Degradasi Moral Anak . Artikel

Noeralamsyah, Zenno. (2012). Konsepsi Agro-Ekonomi Islami; Relasi Metafisik antara Ekonomi dan Ekologi. Jurnal EKBISI, Vol. VII, No. 1, Desember 2012, Hal. 124-135 ISSN:1907-9109

Nota Kesepahaman $(\mathrm{MoU})$ yang dilakukan antara Kementerian Negara Lingkungan Hidup dengan Departemen Agama Nomor: B- 17/DEP.VI/LH/XII/2006 dan Nomor: DJ.II/511E/E/2006, tentang Pengembangan Peran Lembaga Pendidikan Islam dalam Pengelolaan Lingkungan Hidup

Nazir, Muhammad. (1988). Metode Penelitian.Jakarta : Ghalia Indonesia.

Nur, Dewi, dkk.. (2004). Pesantren Agribisnis: Pendekatan Formula Area Multifungsi dan Model Konsepsi Pemberdayaan Serta Profil Beberapa Pesantren,.Jakarta: Ditpeka Pontren Ditjen Kelembagaan Agama Islam Depag 
Pemerintah Republik Indonesia. 2010. Desain Induk Pengembangan Karakter Bangsa Tahun 2010-2025

Peraturan Pemerintah No. 101 Tahun 2000 tentang Prinsip-Prinsip Kepemerintahan yang Bai Peraturan Pemerintah No. 101 Tahun 2000 Prinsip-Prinsip Kepemerintahan yang Baik.

Podungge, Rulyjanti. Potensi Bmt (Baitul Mal Wattamwil) Pesantren Guna Menggerakkan Ekonomi Syari'ah Di Masyarakat

Purbatin, Hadi. Pemanfaatan Kelembagaan Pondok Pesantren Bagi Penyuluhan Pertanian Dan Pengembangan Agribisnis. Artikel

Putra, Reza Noormansyah. (2014). Dampak Programpemberdayaan Santri Dalam Meningkatkan Kesejahteraan Melalui Kegiatan Agribisnis. Skirpsi : Tidak Diterbitkan

Ringkasan Disertasi Sapriya. (2007). Persfektif pemikiran Pakar Pendidikan Kewarganegaraan dalam Pembangunan Karakter Bangsa

Sadulloh, U. (2007). Pengantar Filasafat Pendidikan. Bandung: Alfabeta

Santrok J.W. (1995). Life Span Development. Jakarta: Erlangga

Sapriya. (2007).Persfektif pemikiran Pakar Pendidikan Kewarganegaraan dalamPembangunan Karakter Bangsa. Disertasi Doktor Pada Program Pascasarjana Universitas Pendidikan Indonesia: Tidak diterbitkan

Slavin, R.E. (2000). Educational Psychology: Theory and Practice. Sixth Edition. Boston: Allyn and Bacon

Sugiyono. (2012). Metodologi Penelitian Pendidikan Pendekatan Kualitatif, Kuantitatif R\&D. Bandung: Alfabeta

Suhartini, Dkk. (2005). Model-model Pemberdayaan Pesantren. Yogyakarta:Pustaka Pesantren

Sumodiningrat, Gunawan. (1999). Pemberdayaan Masyarakat \& JPS. Jakarta: PT Gramedia Pustaka Utama

Surat Keputusan Dirjen Dikti No. 163/U/2007 tentang penataan dan Kodifikasi Program Studi Pada perguruan Tinggi

Surat Keputusan Menteri Pertanian no. 555/KPRS/OT.210/6/97, tentang model pengembangan pendidikan keterampilan agrobisnis di pesantren

Tedi Erviantono. Desentralisasi Dan Kemandirian Kelembagaan Lokal. Jurnal Jurusan Ilmu Politik Universitas Brawijaya Malang

Umiarso. (2011). Kependidikan dan Kecerdasan Spiritual. Jogjakarta: Ar-Ruzz

Undang-Undang Nomor 20 Tahun 2002 tentang Sistem Pendidikan Nasional

Undang-Undnag Dasar Negara Republik Indonesia Tahun 1945

Undang-Undang Nomor 23 Tahun 2014 tentang Pemerintahan Daerah

Wahab, A \& Sapriya. (2011). Teori dan Landasan Pendidikan Kewarganegaraan. Bandung: Alfabeta.

Yodhoyono, S.B. Orientasi Pendidikan Masa Kini. Tersedia dalam Kompas terbit tanggal 30 Oktober 2009.

Yodhoyono, S.B. Orientasi Pendidikan Masa Kini. Tersedia dalam Kompas terbit tanggal 30 Oktober 2009.

Yudi Rustandi. (2010). Identifikasi Perilaku Santri Pada Pengembangan Kompetensi Agribisnis (Studi Pemberdayaan Santri Di Pondok Pesantren Al Itifaq Ciwidey-Bandung. Tesis : Diterbitkan

Zenno Noeralamsyah (2012) . Konsepsi Agro-Ekonomi Islami; Relasi Metafisik antara Ekonomi dan Ekologi. Jurnal: Ekonomi dan Bisnis Islam | Vol. VII, No. 1, Desember 2012. Bogor : Program Magister Ekonomi Islam UIKA

Ziemek, Manfred. (1986). Pesantren Dalam Perubahan Sosial. Jakarta: P3M 